\title{
22. FLUID FLOW WITHIN THE BARBADOS RIDGE COMPLEX, PART II: PERMEABILITY ESTIMATES AND NUMERICAL SIMULATIONS OF FLOW VELOCITIES AND PORE PRESSURES1
}

\author{
Dennis R. Wuthrich, ${ }^{2,3}$ Elizabeth J. Screaton, ${ }^{2,4}$ and Shirley J. Dreiss ${ }^{2}$
}

\begin{abstract}
Measurements of sediment physical properties and pore-water chemistry gathered during ODP Leg 110 and DSDP Leg 78A suggest that (1) fluid flow in the décollement is predominantly updip, and (2) near-lithostatic pore pressures may exist just above the décollement at Site 542. We use these observations to constrain a numerical model of fluid flow in the toe of the complex.

Gravitational and tectonic forces drive flow within the complex and are incorporated in the numerical model by estimating the rate and distribution of fluid generation from sediment compaction. Modeling results reveal that near-lithostatic fluid pressures could form at Site 542 if the equivalent prism permeability is between $10^{-18}$ and $10^{-19} \mathrm{~m}^{2}$ (hydraulic conductivity of $10^{-9}$ to $10^{-10} \mathrm{~cm} / \mathrm{s}$ ). Predominantly horizontal flow in the décollement can occur if the décollement permeability exceeds the equivalent prism permeability by three to four orders of magnitude. Under these conditions, average linear fluid velocities in the décollement range between 3 and $10 \mathrm{~cm} / \mathrm{yr}$ (1.5 to 5 times the convergence rate). Fluid velocities in the prism are about 1000 times slower. Depending on the permeability contrast between the décollement and the underthrust sediments, between $65 \%$ and $90 \%$ of the fluids expelled beneath the accretionary prism flow out of the complex through the décollement.
\end{abstract}

\section{INTRODUCTION}

Gravitational and tectonic forces at convergent margins strongly deform accreting oceanic sediments. These forces pressurize pore fluids, initiating fluid flow within the accretionary complex. Because pressurized fluids change the state of stress acting on sediments, fluids strongly influence the structural evolution of accretionary complexes (Hubbert and Rubey, 1959; von Huene and Lee, 1983; Davis et al., 1983). Davis et al. (1983) suggest that pressurized fluids facilitate sliding along the base of critically tapered wedges. In addition, migrating fluids transport chemical species and heat through accretionary complexes, influencing diagenetic and metamorphic reactions (Langseth and Hobart, 1984). Thus, understanding the magnitude and distribution of pore pressures as well as fluid-flow paths is vital to describing the structural and chemical evolution of convergent margins.

Fluid-flow directions, flow rates, and pore-pressure distributions within most convergent margins remain poorly understood. A major achievement of ODP Leg 110 was the measurement of variations in pore-fluid chemistries and temperatures with depth in drill holes (Moore, Mascle, Taylor, et al., 1988). Methane, chloride, and temperature anomalies (Gieskes, et al., in press) suggest preferential flow along the décollement with little flow into the prism (Moore, Mascle, Taylor, et al., 1988). In addition, an "inadvertent packer test" (Moore and Biju-Duval, 1984) performed during DSDP Leg 78A at Site 542 suggests that nearlithostatic fluid pressures may exist just above the décollement. These observations provide important constraints on fluid-flow

\footnotetext{
${ }^{1}$ Moore, J. C., Mascle, A., et al., 1990. Proc. ODP, Sci. Results, 110: College Station, TX (Ocean Drilling Program).

2 Earth Sciences Board, University of California at Santa Cruz, Santa Cruz, CA 95064 .

${ }^{3}$ Current address: Geomatrix Consultants, One Market Plaza, Spear Street Tower, Suite 717, San Francisco, CA 94117.

4 Current address: Harding Lawson and Associates, 7655 Redwood Blvd., P.O. Box 578, Novato, CA 94928.
}

directions and pore pressures within the Barbados Ridge Complex.

Pore pressures and fluid-flow paths depend in part on the permeability distribution within the complex. Unfortunately, direct measurements of sediment permeability in the Barbados Ridge Complex are scarce. Marlow et al. (1984) carried out laboratory permeability measurements on sediments recovered from shallow depths within the prism. However, few permeability measurements have been made on décollement sediments and no in-situ permeability tests have been successfully performed within the Barbados Ridge Complex. Nevertheless, a range of reasonable permeability values can be estimated using the lithologies of samples recovered during drilling. Several studies (Brace, 1980; Morin and Silva, 1984; Morrow et al., 1984; Nuezil, 1986) have measured the permeability of sediments similar to those found within the Barbados Ridge Complex. We base our initial estimates of permeability within the complex on these studies.

In this paper, we use a numerical model to test reasonable ranges of permeabilities for the lithologies encountered within the complex, and observe which permeability distributions produce pore pressures and flow paths consistent with constraints inferred from observations. Those permeability distributions that best match the constraints allow us to estimate fluid flow velocities, overall pore-pressure distributions, and flow paths.

\section{TECTONIC SETTING}

The Barbados Ridge Complex is located east of the Lesser Antilles volcanic arc, where the Atlantic Ocean crust subducts beneath the Caribbean Plate (Fig. 1). The rate of this convergence has been estimated as 2.0 to $2.2 \mathrm{~cm} / \mathrm{yr}$ (MacDonald and Holcombe, 1978; Minster and Jordan, 1978; Tovish and Schubert, 1978; Dorel, 1981), with $2 \mathrm{~cm} / \mathrm{yr}$ considered most plausible (Stein et al., 1988). At the Leg 110 drilling sites, the complex is dominated by fine-grained sediments of low intrinsic permeability (Marlow, et al., 1984; Taylor and Leonard, this volume). Seismic reflection studies and drilling results document the presence of a laterally extensive, well-developed décollement (Westbrook and Smith, 1983). The décollement extends over 100 $\mathrm{km}$ westward beneath the complex, and separates off-scraped, 

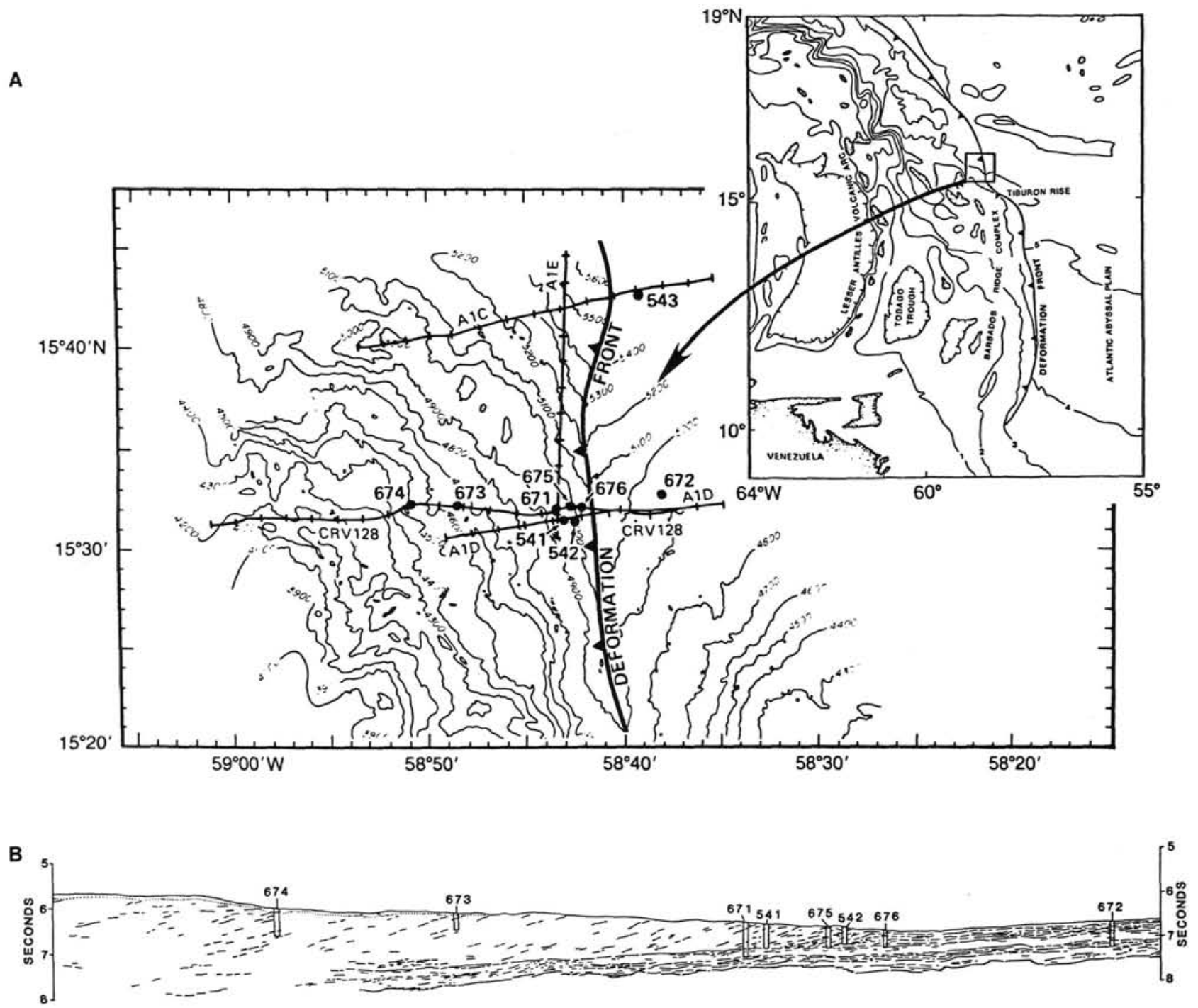

Figure 1. Location map showing ODP 110 and DSDP Leg 78A drilling sites and seismic reflection lines (A) and seismic cross-section CRV128 with superimposed sites and penetrations (B). (From Mascle, Moore, et al., 1988.)

deformed sediments of the accretionary prism from little-deformed, acoustically coherent underthrust sediments.

Cores recovered during both ODP Leg 110 and DSDP Leg 78A (Wright, 1984) document several different lithologies within the Barbados Ridge Complex. Prism sediments are typically fine grained, and consist predominantly of both pelagic calcareous mudstones and hemipelagic clays (Moore, Mascle, Taylor et al., 1988). Seismic reflection profiles and samples recovered from cores suggest that the accretionary prism consists of fault-bounded packets of deformed, tectonically mixed sediments (Brown, et al., this volume). Décollement sediments are primarily radiolarian-bearing mudstones with a well-developed scaly fabric (Moore, Mascle, Taylor et al., 1988). Samples obtained from below the décollement in the underthrust sequence of sediments include clays and sands. Seismic reflection images suggest that these sediments are well-bedded, forming prominent sub-horizontal reflectors.

\section{FLUID-FLOW MODEL}

In this study, we focus on fluid flow and pore pressures in a cross-section along seismic line CRV128 (Fig. 1). The model boundaries extend from $10 \mathrm{~km}$ seaward of the deformation front to $14 \mathrm{~km}$ arcward of the front. These boundaries were chosen to minimize the influence of boundary effects and to reduce the uncertainty in the model simulations in the center of the flow field.

\section{Conceptual Background and Modeling Assumptions}

Gravitational and tectonic forces load sediments as they enter the complex. These loads are initially balanced by a rise in pore-fluid pressures. Water flows from pore spaces in response to these increased fluid pressures, allowing sediments to compact. However, if flow rates from the sediments are slower than the rate of sediment loading, fluid pressures increase (Bredehoeft and Hanshaw, 1968). Pore pressures can build this way as long as stress is applied to the sediment, until the sediments rupture either by hydrofracturing or faulting (Hubbert and Willis, 1957). Gradients in hydraulic head and sediment permeabilities determine the magnitude and direction of fluid flow through the complex.

ln the first paper of this series, Screaton et al. (this volume) estimate the volume of fluids expelled as sediments deform under steady-state sediment flux conditions. This approximation assumes that the complex remains at critical taper for a refer- 
ence frame that translates with the deformation front, and that the amount and distribution of mass flux of sediments through the complex does not vary with time. This results in a constant sediment porosity distribution through time, and hence a time invariant distribution of sediment dewatering rates. We incorporate these dewatering rates into the flow model as a way to approximate the effects of sediment deformation on fluid flow. Because the sediment dewatering rates remain constant through time, we can simulate fluid flow through the complex using a steady-state formulation.

\section{Theoretical Background}

A general description of fluid flow in a deforming, saturated, porous medium begins with the conservation of mass of liquids and solids in a fixed control volume (Bear, 1972).

$$
\begin{gathered}
\vec{\nabla} \cdot\left(\rho_{l} \vec{q}_{l}\right)+\frac{\partial\left(n \rho_{l}\right)}{\partial t}=0 \\
\vec{\nabla} \cdot\left(\rho_{s} \vec{q}_{s}\right)+\frac{\partial\left((1-n) \rho_{s}\right)}{\partial t}=0
\end{gathered}
$$

where

$$
\begin{aligned}
\rho_{l}= & \text { fluid density }\left(\mathrm{M} / \mathrm{L}^{3}\right) ; \\
\vec{q}_{1}= & \text { specific discharge of fluids relative to a fixed coordi- } \\
& \text { nate system }(\mathrm{L} / \mathrm{T}) ; \\
\rho_{s}= & \text { density of solid grains }(\mathrm{M} / \mathrm{L}) ; \\
\vec{q}_{s}= & \text { specific discharge of solids relative to a fixed coordi- } \\
& \text { nate system }(\mathrm{L} / \mathrm{T}) ; \text { and } \\
n= & \text { porosity. }
\end{aligned}
$$

The first terms in (1) and (2) represent the divergence of the fluid and solid mass fluxes (the net difference of inflow and outflow through a control volume). The second terms define changes in mass storage with time. Because we assume a steady-state porosity distribution and a constant fluid density, $\rho_{l}$, and solid density, $\rho_{s}$,

$$
\nabla \cdot(\vec{q})=0
$$

and

$$
\vec{\nabla} \cdot\left(\vec{q}_{s}\right)=0
$$

Darcy's law describes the velocity of the liquids relative to the solids as

$$
\vec{V}_{r}=\frac{-k}{n \mu}\left(\vec{\nabla} p-\rho_{l} \vec{g}\right)
$$

where $k$ is the intrinsic permeability of the sediments $\left(\mathrm{L}^{2}\right) ; \mu$ is the dynamic velocity of the fluid (M/LT); and $\vec{g}$ is the gravitational vector $\left(\mathrm{L} / \mathrm{T}^{2}\right)$. The velocity of the liquid relative to a fixed coordinate system, $\overrightarrow{\boldsymbol{V}}_{t}$, is related to the velocity relative to the solid matrix, $\vec{V}_{r}$, by

$$
\vec{V}_{l}=\vec{V}_{r}+\vec{V}_{s}
$$

or

$$
\overrightarrow{\boldsymbol{q}}_{l}=\overrightarrow{\boldsymbol{q}}_{r}+n \overrightarrow{\boldsymbol{V}}_{s}
$$

where $\overrightarrow{\boldsymbol{q}}_{t}=\overrightarrow{\boldsymbol{V}}_{1} n, \overrightarrow{\boldsymbol{q}}_{r}=\overrightarrow{\boldsymbol{V}}, n$, and $\overrightarrow{\boldsymbol{V}}_{s}$ is the velocity of the solids (Bear, 1972).
Combining (3), (4), and (6), we obtain a general expression for steady-state fluid flow in a deforming medium. We assume that flow is isothermal, that fluid generation from geochemical reactions is negligible, and that no fluid sources or sinks exist:

$$
\vec{\nabla} \cdot\left(n \vec{V}_{s}\right)=-\vec{\nabla} \cdot \frac{k}{\mu}\left(\vec{\nabla} p-\rho_{l} \vec{g}\right)
$$

The term $\vec{\nabla} \cdot\left(n \vec{V}_{s}\right)$ represents the rate of pore-volume change within a domain with coordinates fixed relative to the deformation front. Thus, if the spatial distribution of $\vec{\nabla} \cdot\left(n \overrightarrow{\boldsymbol{V}}_{s}\right)$ is known, fluid pressures and velocities can be calculated from (7) as a steady-state fluid flow problem.

\section{Numerical Solution}

We use SUTRA (Voss, 1984), a finite-element fluid-flow code, to solve (7). SUTRA approximates the flow equation over each element, solving for the fluid pressure at each node. The finiteelement grid we use for the complex is made up of 442 elements and 490 nodes (Fig. 2). The smaller elements along the décollement and in the toe of the prism provide numerical accuracy in these regions, thereby providing better estimates of pore pressures and flow directions. As a check on the numerical approximation, we doubled the number of nodes in the grid in the vertical direction and observed that the computed pore pressures did not change significantly.

\section{Boundary Conditions}

Boundary conditions describe rates of fluid flow or fluid pressure at the edges of the flow domain (Fig. 2). The sedimentwater interface forms the upper flow boundary, where fluid pressures are hydrostatic and equal the weight of the overlying water column. We treat the underlying basaltic oceanic crust as a no flow boundary. Specifying the lower flow boundary this way assumes that any fractures within the oceanic basement are insignificant avenues of flow, and that fluid production or withdrawal due to mineral phase changes at shallow crustal levels are negligible.

We specify a hydrostatic pressure profile along the seaward boundary of the model, $10 \mathrm{~km}$ east of the deformation front. This assumes that pore fluids in the sediments rafted along the North American Plate have not been overpressured before reaching the boundary, or that this boundary is far enough seaward that simulated pore pressures in the toe of the complex are not affected. Although Shi and Wang (1985) suggest that tectonic forces may begin overpressuring fluids seaward of the deformation front, no evidence of elevated pore pressures, such as mud diapirs, have been recognized seaward of the deformation front near the Leg 110 drilling sites (Brown and Westbrook, in press).

Neither fluid pressures nor flow rates are known at the arcward boundary of the model. However, the presence of thermogenic methane below the prism suggests that flow crosses this boundary through the décollement and underthrust sediments (Vrolijk, this volume). Consequently, we treat the arcward edge of the décollement and underthrust sediments as a specified flux boundary. We estimate the fluid flux across this boundary as one of two end members. As a minimum, no flow is specified. As a maximum, the flow is specified as the rate of total fluid generation that might occur arcward of the boundary if underthrust sediments were to compact to a porosity of 0.10 . Screaton et al. (this volume) describe this calculation in detail. We assume that the arcward prism boundary defines a flow path, allowing the arcward edge of the prism to be treated as a no-flow boundary. 


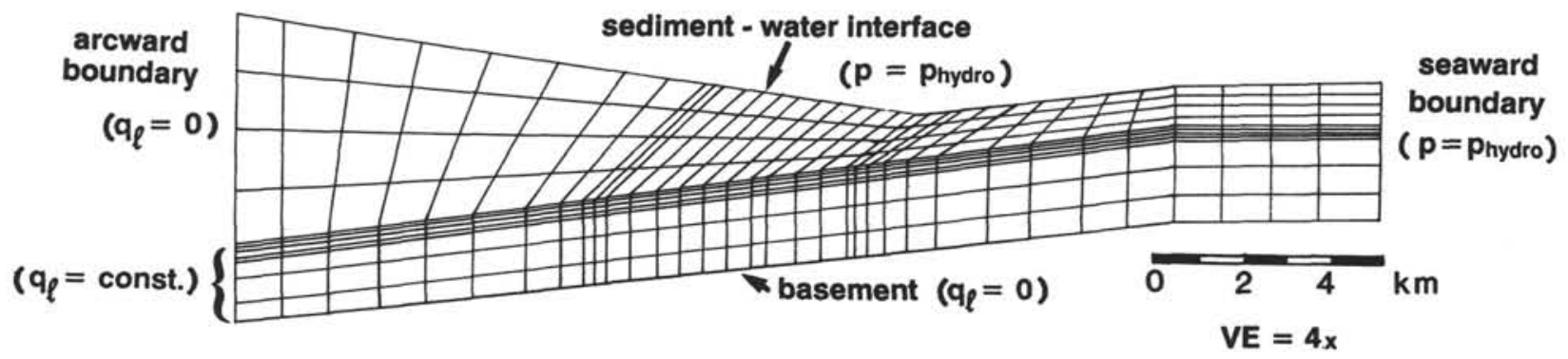

Figure 2. Finite-element grid and boundary conditions for the fluid-flow model.

\section{ESTIMATION OF INTRINSIC PERMEABILITY}

We divide the flow model into three hydrologic domains, corresponding to the prism, décollement, and underthrust sequence. Because of the scarcity of data, we characterize the intrinsic permeability in each domain with a single equivalent permeability. This approach may produce unrealistic fluid pressure in the prism, where $k$ is recognized to vary with depth. On the other hand, if the estimated prism permeability represents sediments immediately above the décollement, simulated pore pressures in the décollement will be close to actual values.

Individual fault zones within the prism cannot be treated explicitly because the frame of reference of the model translates with the deformation front. Instead, the equivalent permeability for the prism $\left(k_{p}\right)$ represents a combination of both fault zone and intergranular permeabilities. The equivalent permeability of the décollement $\left(k_{d}\right)$ represents the fracture permeability of the scaly mudstones found within this zone. The equivalent permeability of the underthrust sediments $\left(k_{u}\right)$ characterizes the average permeability for the sands and mudstones found beneath the décollement. We estimated initial equivalent permeability ranges for each domain by comparing lithologic descriptions of sediments found in the complex to measurements made on similar sediments by other researchers (Morin and Silva, 1984; Morrow et al., 1984). This restricts our search for representative permeabilities in each domain to plausible values.

The abundance of mudstones and marls suggests low equivalent permeabilities for the prism sediments. Marlow et al. (1984) measured the permeabilities of a few samples retrieved from shallow depths within the prism during DSDP Leg 78A, and Taylor and Leonard (this volume) obtained permeability values for several samples from depths up to $450 \mathrm{mbsf}$. These measurements provide preliminary estimates for the intergranular permeability of the prism sediments, and range between $10^{-16}$ and $10^{-21} \mathrm{~m}^{2}$. Sediments deeper in the prism may possess even lower intergranular permeabilities. However, imbricate thrust faults in the prism may act as zones of higher permeability (Moore, Mascle, Taylor et al., 1987), raising the overall equivalent permeability of the prism. Thus, our initial estimates of the equivalent permeability for prism sediments range from $10^{-22} \mathrm{~m}^{2}$ to $10^{-17}$ $\mathrm{m}^{2}$ (corresponding to an hydraulic conductivity for seawater of $10^{-13}$ to $\left.10^{-8} \mathrm{~cm} / \mathrm{s}\right)$.

Unfortunately, no direct measurements of permeability exist for either the décollement or underthrust sediments. We assume that before developing their scaly fabric, the smectitic muds of the décollement possessed an intergranular permeability similar to that of the prism sediments. Studies of fractured media similar to the sheared smectitic clays found in the décollement suggest that fractures can increase the bulk permeability of a sample by as much as four orders of magnitude (Brace, 1980). To ensure that our initial estimates of décollement permeability are not too narrow, we assume that the scaly fabric could increase the intergranular permeability of the décollement clays up to six orders of magnitude. Therefore, initial décollement permeability estimates range between zero and six orders of magnitude more permeable than the prism permeability (Table 1).

The underthrust sediments consist primarily of laterally extensive, bedded, hemipelagic clays and turbiditic sands (Dolan, this volume). These sands plugged up the drill string at Site 671 (Moore, Mascle, Taylor et al., 1988), suggesting that they are only weakly cemented and, thus, may be more permeable than surrounding clays. Hence, we assume the underthrust sediments have a higher average equivalent permeability than the claydominated prism sediments. However, the equivalent permeability of the underthrust sediments is probably lower than that of the fracture-dominated décollement. Therefore, we treat this zone as intermediate in permeability between the prism and décollement, allowing the equivalent permeability to vary between zero and five orders of magnitude greater than the prism (Table 1).

\section{FLUID-FLOW SYSTEM}

Using the fluid-flow model, we investigated how varying the permeability in each domain affects fluid-flow paths and porepressure distributions throughout the complex. First, we used observations from Legs 110 and $78 \mathrm{~A}$ to infer fluid-flow directions and pore pressures at specific sites within the complex. These observations provided fluid-pressure and flow-path constraints that model simulations should match. We then performed a sensitivity analysis by varying the permeability of each domain and comparing simulated pore pressures and flow paths to the constraints.

\section{Observations Constraining Fluid Pressures and Flow Directions}

Observations from Legs 110 and $78 \mathrm{~A}$ suggest that (1) fluid flow within the décollement is primarily lateral; and (2) that near-lithostatic pore pressures exist just above the décollement at Site 542 .

Measurements of pore-water chemistry made during Leg 110 reveal very low methane concentrations in the prism sediments, while concentrations within and below the décollement are an order of magnitude higher (Gieskes et al., in press). Figure 3 shows methane concentrations at Site 671 of about $20 \mu \mathrm{M}$

Table 1. Initial permeability estimates for the prism, décollement, and underthrust sediments.

\begin{tabular}{lcc}
\hline & \multicolumn{2}{c}{ Intrinsic permeability $\left(\mathrm{m}^{2}\right)$} \\
\cline { 2 - 3 } & maximum & minimum \\
\hline Prism $\left(k_{p}\right)$ & $10^{-17}$ & $10^{-22}$ \\
Décollement $\left(k_{d}\right)$ & $10^{-11}$ to $10^{-17}$ & $10^{-16}$ to $10^{-22}$ \\
Underthrust sediments $\left(k_{u}\right)$ & $10^{-12}$ to $10^{-17}$ & $10^{-17}$ to $10^{-22}$ \\
\hline
\end{tabular}




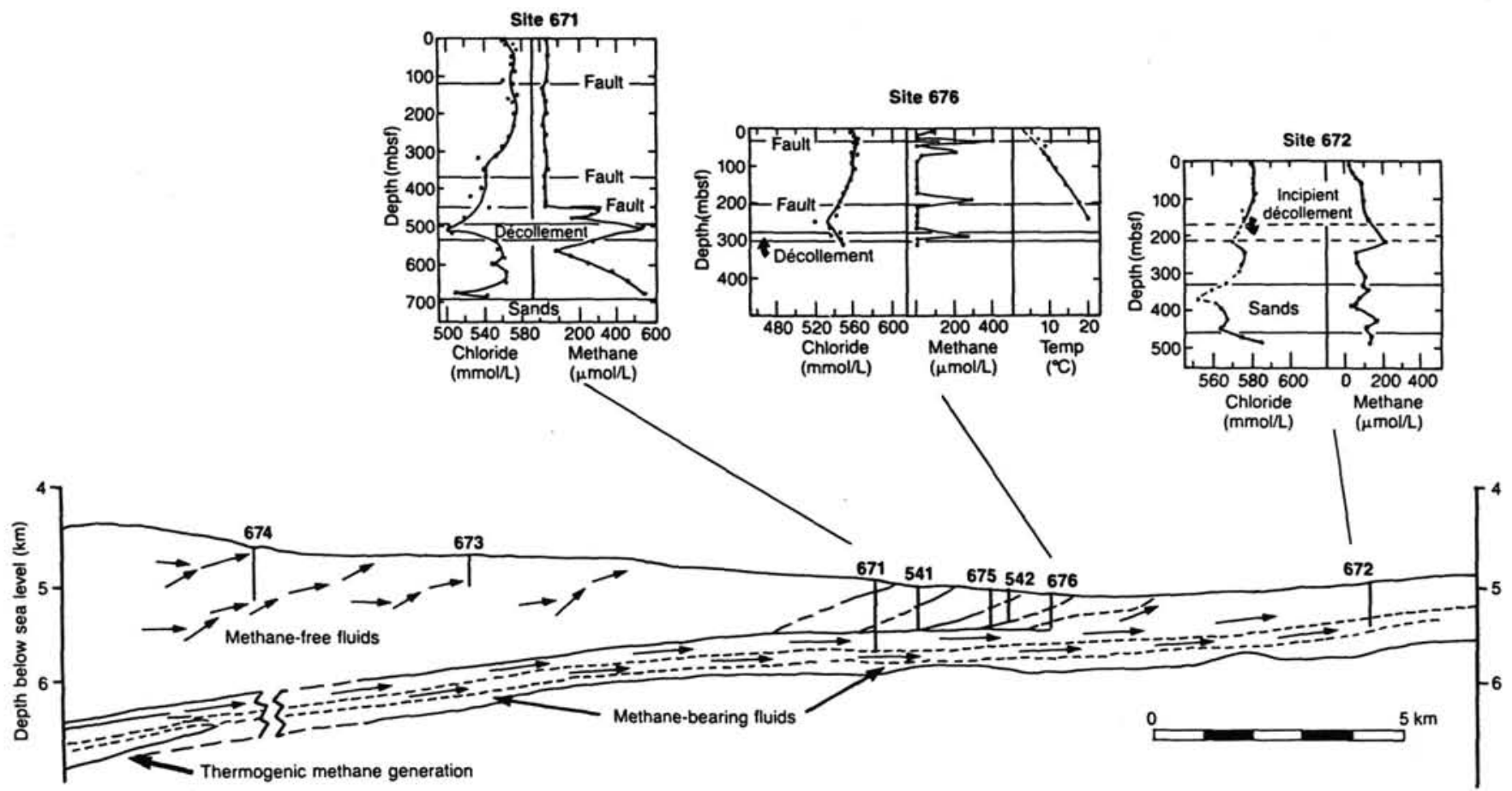

Figure 3. Drilling site locations, methane and chloride concentrations, and temperature anomalies in prism and décollement sediments at Sites 671 and 672 (from Moore, Mascle, Taylor, et al., 1988, and Gieskes et al., in press).

within the prism, with a sharp increase in concentration in the décollement. This anomaly in methane concentration is also apparent at Site 672 , although concentrations do not increase as sharply across the décollement as they do at Site 671 .

Gas chromatograph analysis and the absence of organic matter in the underthrust sediments suggest a thermogenic origin for the sampled methane (Gieskes et al., in press). However, bottom-hole temperatures in the toe of the complex are not high enough to form thermogenic methane even in the Eocene underthrust sediments (Vrolijk, this volume). Thus, the sampled methane must originate at warmer, and therefore deeper locations than the ODP sites. Thermogenic methane forms at a minimum temperature of approximately $100^{\circ} \mathrm{C}$, corresponding to depths of 3 to $4 \mathrm{~km}$. These depths are first reached approximately $60 \mathrm{~km}$ arcward of the deformation front, suggesting significant lateral migration of methane-bearing fluids (Vrolijk, this volume).

An increase in methane concentrations in prism sediments from Site 671 to Site 672 and higher concentration spikes associated with fault zones indicate leakage from the décollement into the prism. In addition, differences in chloride concentrations between the décollement and prism and decreasing chloride concentration with depth in the prism both suggest that some flow occurs from the décollement into the prism.

An "inadvertent packer test" performed at Site 542 of DSDP Leg 78A (Moore and Biju-Duval, 1984) indicated that nearlithostatic fluid pressures may exist just above the décollement, approximately $4 \mathrm{~km}$ arcward of the deformation front. Unstable hole conditions and fluidized sediments encountered during both ODP and DSDP drilling programs support the existence of high fluid pressures in the toe of the complex.

\section{Sensitivity Analysis}

Figure 4 illustrates a representative fluid flow pattern and plot of hydraulic head assuming a prism permeability of $10^{-18}$ $\mathrm{m}^{2}$, a décollement permeability of $10^{-14} \mathrm{~m}^{2}$, and an underthrust permeability of $10^{-15} \mathrm{~m}^{2}$. Water originating in the décollement and underthrust sediments flows laterally through the complex. In contrast, water expelled from prism sediments flows upward to the ocean floor. We now examine how flow patterns and associated pore pressures vary for different assumed permeability values in each domain and compare simulation results to constraints from Legs $78 \mathrm{~A}$ and 110 .

\section{Effect of Permeability on Fluid Pressures}

The pore-pressure ratio, $\lambda^{*}$, is commonly used to describe the magnitude of fluid pressures in a sedimentary sequence relative to the overburden load (Hubbert and Rubey, 1959; Davis, 1984). $\lambda^{*}$ expresses fluid pressures at a point in terms of lithostatic and hydrostatic pressures and is defined by Shi and Wang (1988) as:

$$
\lambda^{*}=\left(p-p_{\text {hydro }}\right) /\left(p_{\text {lith }}-p_{\text {hydro }}\right)
$$

where:

$$
\begin{array}{ll}
p & =\text { pore fluid pressure } \\
p_{\text {hydro }} & =\text { hydrostatic fluid pressure; }
\end{array}
$$

and

$$
p_{\text {lith }}=\text { lithostatic pressure. }
$$

$\lambda *$ represents the ratio of excess fluid pressures, i.e., fluid pressure above hydrostatic relative to the sediment overburden pressure. Defining $\lambda^{*}$ in this way removes the effect of the overlying water column when describing fluid pressures within the complex. For lithostatic pore pressures, $\lambda^{*}=1$; at hydrostatic pressures, $\lambda^{*}=0$.

The equivalent permeability of the prism sediments, $k_{p}$, and the contrast between the equivalent décollement permeability 

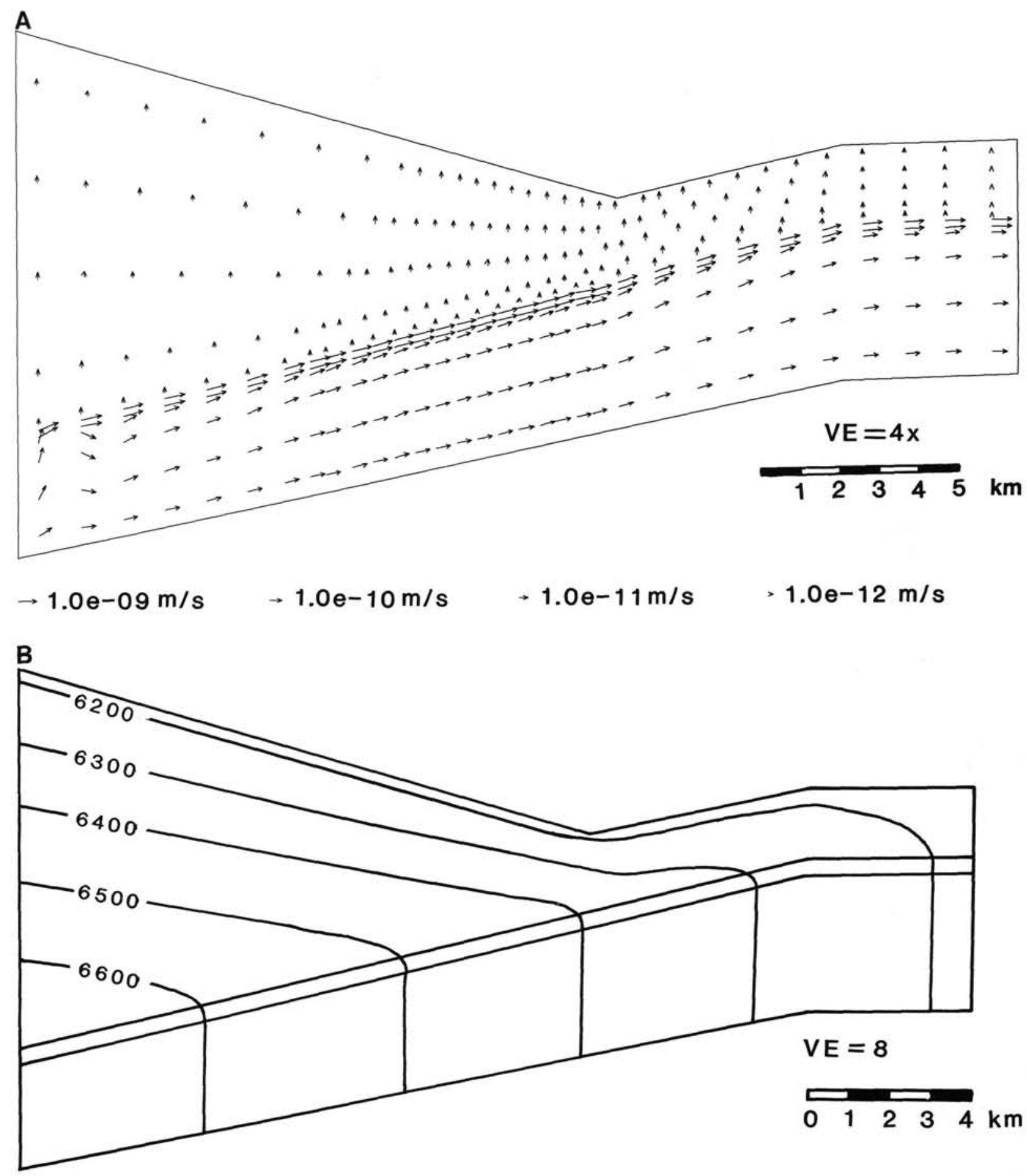

Figure 4. Computed fluid-flow vectors (A) and hydraulic head contours (B) for a complex with an equivalent prism permeability of $10^{-18}$ $\mathrm{m}^{2}$, décollement permeability of $10^{-14} \mathrm{~m}^{2}$, and underthrust permeability of $10^{-15} \mathrm{~m}^{2}$. Arcward boundary flux is zero through the prism sediments, $4.39 \times 10^{-9} \mathrm{~m}^{3} / \mathrm{s}$ into the décollement, and $8.15 \times 10^{-8} \mathrm{~m}^{3} / \mathrm{s}$ into the underthrust sequence. Vector length is scaled to the natural $\log$ of the flow velocity.

and the equivalent prism permeability, $k_{d} / k_{p}$, greatly affect the magnitude of simulated pore fluid pressures at Site 542. Figure 5 illustrates $\lambda^{*}$ values at the top of the décollement at Site 542 for a range of prism permeabilities, $k_{d} / k_{p}$ contrasts, and $k_{d} / k_{u}$ contrasts. Equivalent prism permeabilities must be $10^{-18} \mathrm{~m}^{2}$ $\left(10^{-9} \mathrm{~cm} / \mathrm{s}\right)$ or less to produce near-lithostatic $\left(\lambda^{*}>0.8\right)$ pore pressures at this location. However, equivalent prism permeabil- ities of $10^{-20} \mathrm{~m}^{2}\left(10^{-11} \mathrm{~cm} / \mathrm{s}\right)$ or lower produce unrealistically high $\left(\lambda^{*} \gg 1\right)$ pore pressures that greatly exceed the lithostatic load. Effective prism permeabilities greater than $10^{-17} \mathrm{~m}^{2}$ lead to almost hydrostatic $\left(\lambda^{*}<0.1\right)$ pore pressures at the test site.

Increasing the $k_{d} / k_{p}$ contrast while holding the prism permeability constant lowers the fluid pressure at Site 542 (Fig. 5). Thus, a relatively permeable décollement can dissipate fluid 


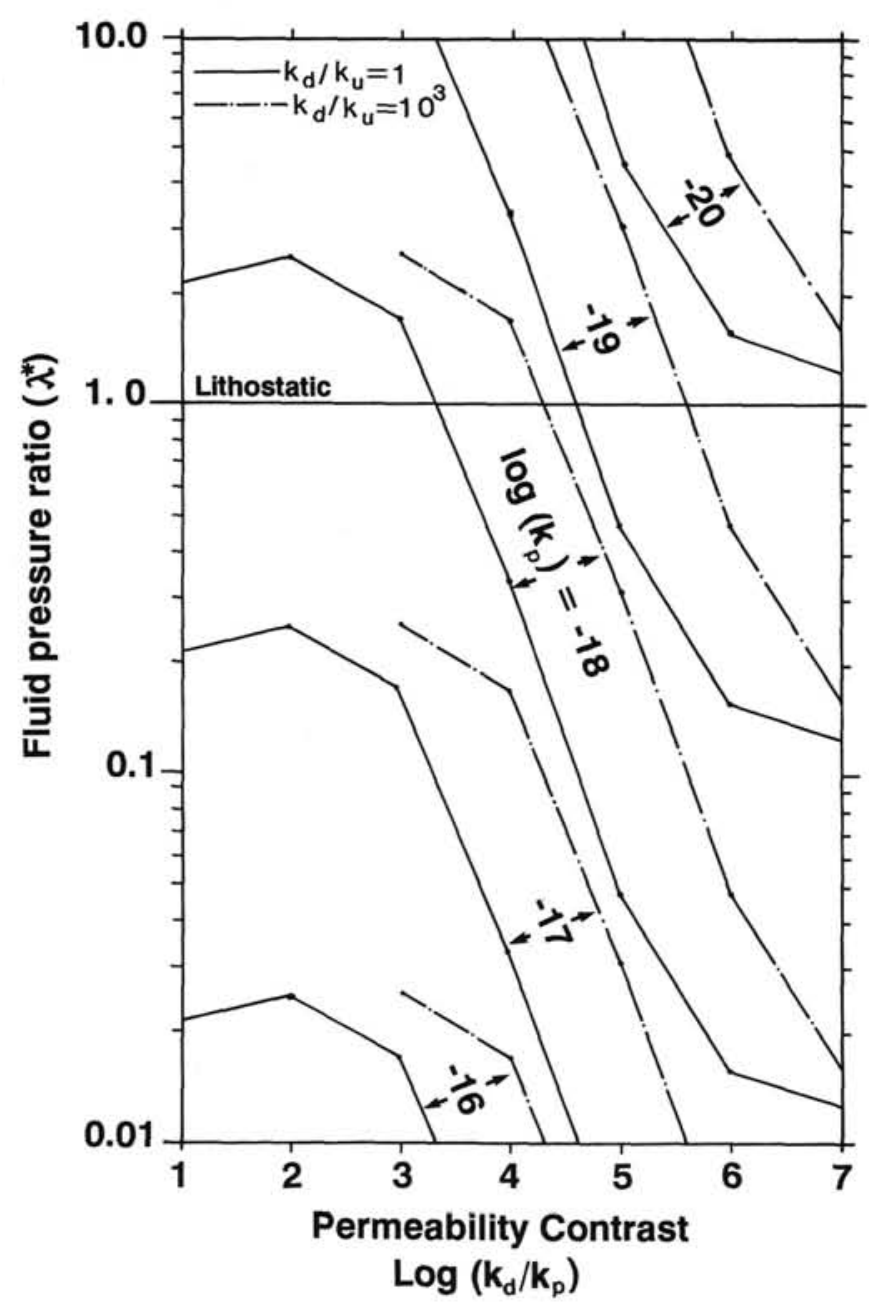

Figure 5. Computed pore-pressure ratios, $\lambda^{*}$, in the décollement at Site 542 for various equivalent prism permeabilities, $k_{p}$, and contrasts in permeability between the prism and décollement, $k_{d} / k_{p}$. Solid lines connect cases with equal décollement and underthrust equivalent permeabilities; dashed lines represent cases with a décollement three orders of magnitude more permeable than the underthrust sediments.

pressures within a low permeability accretionary complex. However, the permeability contrast between the décollement and the underthrust sequence $\left(k_{d} / k_{u}\right)$ does not greatly affect the pressures just above the décollement. For example, a $k_{d} / k_{u}$ contrast of three orders of magnitude has less effect on fluid pressures at Site 542 than a one order of magnitude change in prism permeability.

\section{Effect of Permeability Contrasts on Flow Directions}

The permeability contrasts between the décollement and prism $\left(k_{d} / k_{p}\right)$, and between the décollement and the underthrust sediments $\left(k_{d} / k_{u}\right)$ also influence fluid-flow directions within the complex. For a $k_{d} / k_{p}$ contrast greater than five orders of magnitude, water moves downward from the prism into the décollement, violating the upward flow constraint (Fig. 6A). Thus, a very permeable décollement acts as a drain, drawing water from the prism. To simulate predominantly horizontal flow in the décollement, the equivalent permeability contrast between the prism and décollement must exceed three orders of magnitude. Lower contrasts between the two zones result in a significant component of upward flow from the décollement into the prism, in-
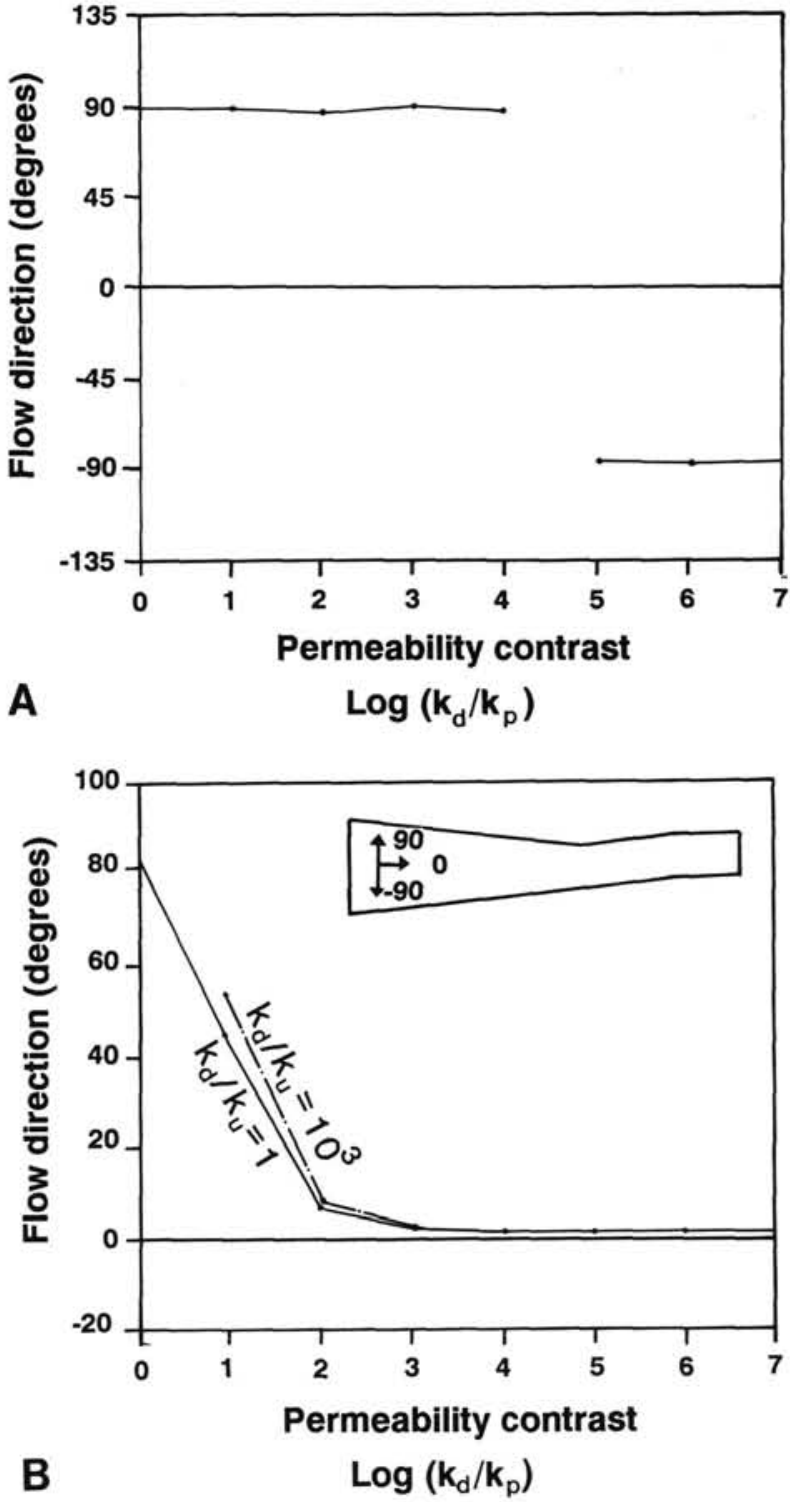

Figure 6. (A) Computed flow directions in the prism décollement five orders of magnitude or greater more permeable than the prism draws fluids down from the prism, violating the flow constraints. (B) Computed flow directions in the décollement. Predominantly horizontal flow in the décollement requires a $k_{d} / k_{p}$ contrast of at least three orders of magnitude.

consistent with the flow constraints (Fig. 6B). Thus, the permeability contrast between the décollement and the prism $\left(k_{d} / k_{p}\right)$ must range between $10^{3}$ and $10^{5}$ to match observations. Because we assume that the equivalent décollement permeability always exceeds the equivalent permeability of the underthrust sediments, $k_{d} / k_{u}$ does not greatly affect simulated flow directions in the décollement.

\section{Effect of Porosity Distribution on Fluid Pressures}

Pore pressures at Site 542 are not greatly affected by the amount of flux of water across the arcward décollement and underthrust sediment boundary (Fig. 7). However, fluid-flow rates in the décollement and underthrust sediments increase approximately $100 \%$ between the minimum no-flow boundary case and the maximum flux case computed by Screaton et al. (this volume). Because both fluid chemistry and heat measurements sug- 


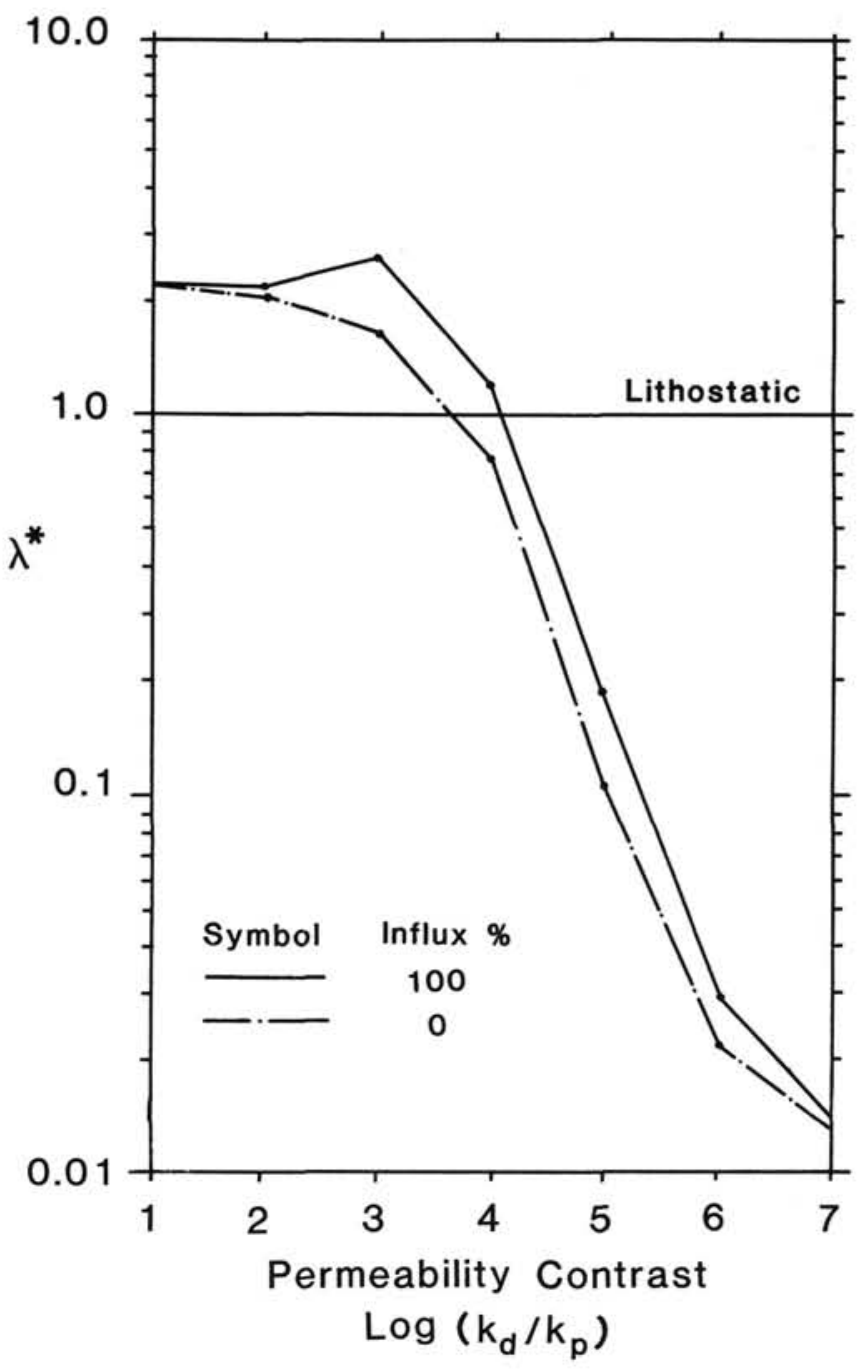

Figure 7. Effect of arcward boundary flux on fluid pressures in the décollement at Site 542. The dotted line represents pressures computed using a no-flow arcward boundary condition for the décollement and underthrust sediments. The solid line shows pressures computed with the maximum flux condition. The boundary flux affects fluid pressures much less than an order of magnitude change in prism permeability.

gest flow from depth, we use the maximum flux case in most of our simulations.

\section{Effect of Porosity Distribution on Fluid Pressures}

The sediment porosity distribution is used in computation of sediment dewatering (Screaton et al., this volume). Thus, our estimates of sediment porosity influence the simulated pressure distribution and flow field. Figures $8 \mathrm{~A}$ and $8 \mathrm{~B}$ illustrate several alternative porosity-depth relationships for the prism and the décollement. To test how sensitive the model is to these relationships and resulting sediment dewatering rates, we varied the porosity distribution of the prism and décollement between the end members shown in Figures $8 \mathrm{~A}$ and $8 \mathrm{~B}$, and recalculated the amount of water expelled during sediment compaction.

The $\lambda^{*}$ in the décollement and the prism is not very sensitive to plausible variations in the porosity distribution in the complex. Use of Curve 2 rather than Curve 1 in Figure 8 decreased the minimum porosity in the prism and décollement to 0.2 and 0.3 , respectively, produced $9 \%$ more water throughout the com-
A

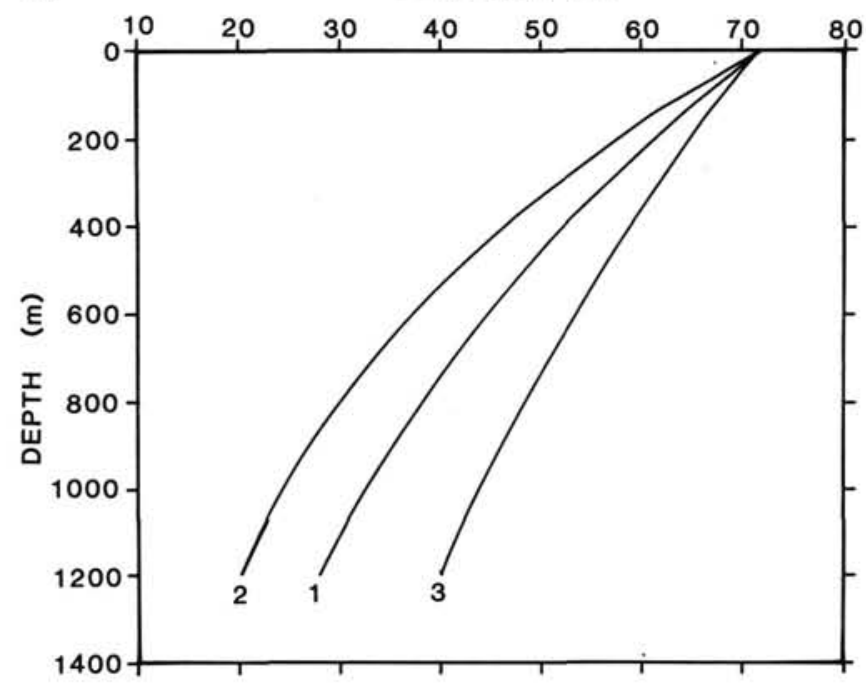

B

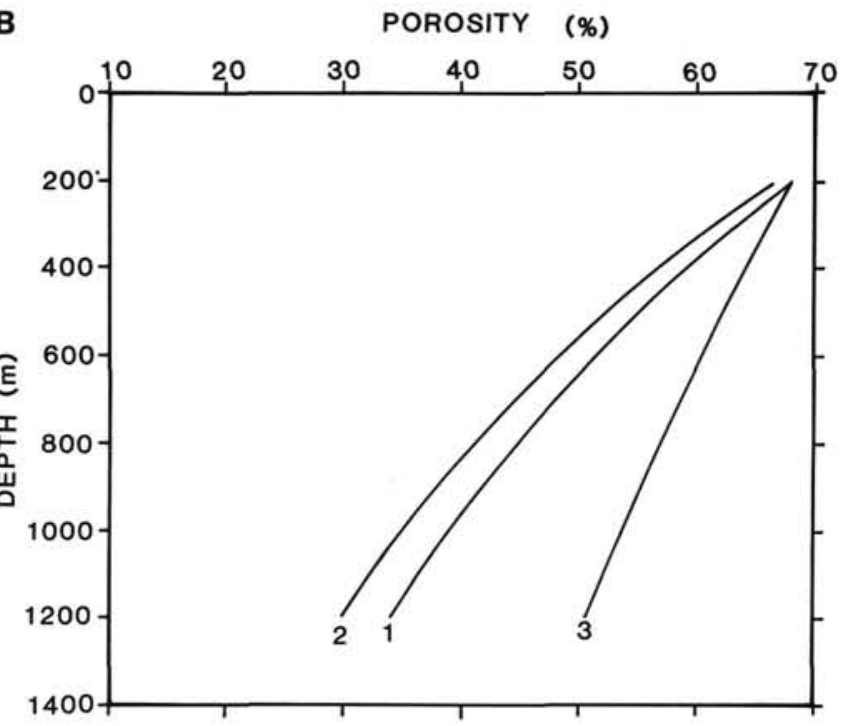

Figure 8. (A) Estimates of porosity-depth relationships for the prism sediments. Curve 1 is a least-squares fit of Leg 110 porosity data. Curves 2 and 3 represent alternative high and low porosity-depth gradients, respectively. (B) Estimates of porosity-depth relationships for the décollement sediments. Curves 1, 2, and 3 represent best-fit, high- and low-porosity gradients, respectively.

plex, and as much as $20 \%$ more water at nodal points near Site 542. The decrease raised fluid pressures at the top of the décollement by only about $2 \%$ (Fig. 9A). However, $\lambda^{*}$ decreased because the increased fluid pressure did not compensate for the greater lithostatic load created by a sediment with a higher bulk density. Using Curve 3 and increasing the porosity in the prism and décollement to 0.4 and 0.5 , respectively, resulted in a $17 \%$ decrease in total fluid production throughout the complex, up to a $45 \%$ decrease in fluid production around nodes near Site 542 , and a $3 \%$ drop in fluid pressures at Site 542 (Fig. 9B). However, $\lambda^{*}$ increased despite the decrease in fluid expulsion rate because the lithostatic load was less for the more porous sediment. Overall, simulated pore pressures and are much less sensitive to plausible variations in porosity distribution than to feasible variations in prism permeability. 


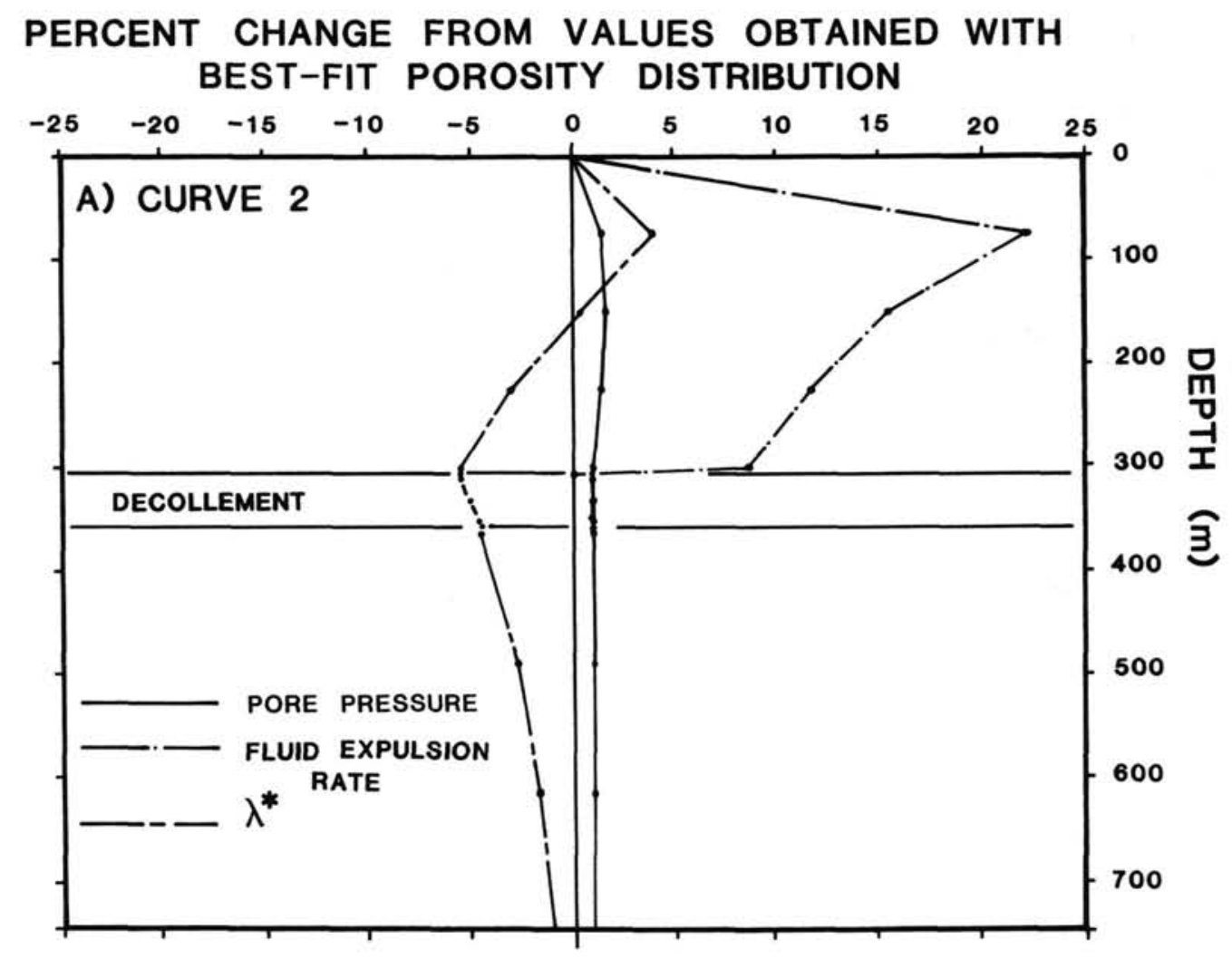

\section{PERCENT CHANGE FROM VALUES OBTAINED WITH} BEST-FIT POROSITY DISTRIBUTION

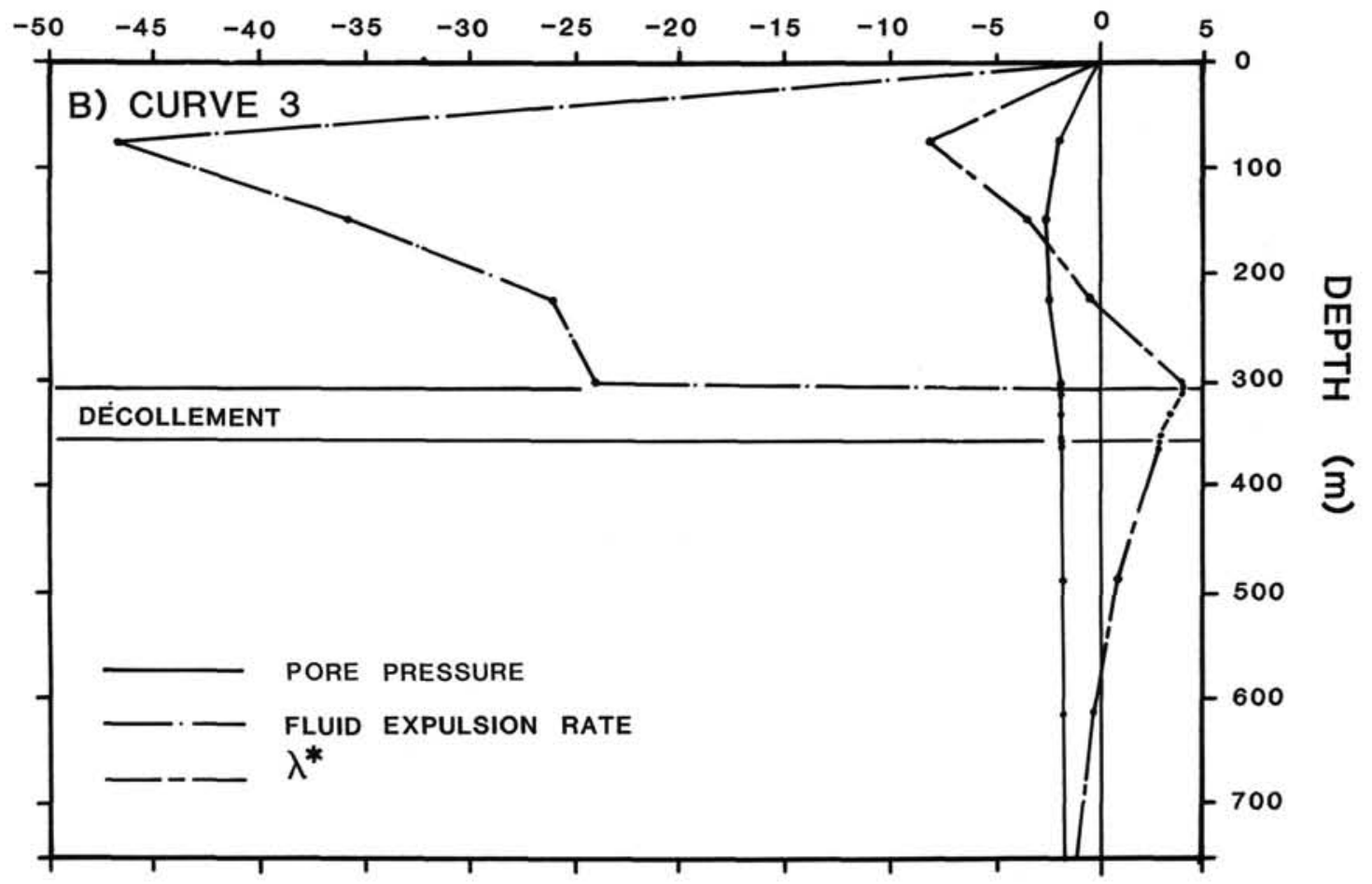

Figure 9. Sensitivity of computed expulsion rates, pore pressures, and $\lambda^{*}$ at DSDP Site 542 to porosity distribution. (A) Comparison between best-fit curve and curve 2 , which represents a relatively large change in porosity with depth. (B) Comparison between best-fit curve and curve 3 , representing a relatively small change in porosity with depth. 


\section{Results and Implications of Numerical Modeling}

Only a few combinations of intrinsic permeability produce flow patterns and fluid pressures consistent with pore-water chemistry observations (Table 2).

\section{Fluid-Flow Directions and Rates}

Water originating within the décollement and underthrust sediments flows laterally through the complex (Fig. 4). Depending on the $k_{d} / k_{u}$ contrast, between $65 \%$ and $90 \%$ of the water expelled during sediment consolidation beneath the prism leaves the complex along the décollement. Average fluid velocities range between 3 and $10 \mathrm{~cm} / \mathrm{yr}$, or about 1.5 to 5 times the convergence rate.

In contrast to flow within the décollement, water expelled from prism sediments flows upward through the complex toward the ocean floor. These fluids represent approximately one third of the total volume of water produced by sediment consolidation within the toe of the Barbados Ridge Complex (Screaton et al., this volume). Because of the low prism permeabilities, fluid velocities are low, ranging between 0.003 and $0.01 \mathrm{~cm} / \mathrm{yr}$. These velocities represent regional flow rates through the accretionary prism. Actual local velocities in the prism are controlled by structural and stratigraphic features, and cannot be explicitly considered in a regional scale model. For example, imbricate thrust faults near the deformation front may episodically perturb fluid-flow patterns, locally allowing much higher rates of flow through the prism. Thus, the regional scale velocities and flow directions calculated in the model represent temporal and spatial averages of fluid flow through the complex.

\section{Fluid Pressures}

Fluid pressures in the décollement increase arcward from the deformation front. However, average $\lambda^{*}$ in the décollement decreases arcward from the deformation front despite these higher fluid pressures (Fig. 10). This trend in $\lambda^{*}$ results from the arcward thickening in the prism. Prism sediment thicknesses vary from only $200 \mathrm{~m}$ at the deformation front to approximately $1000 \mathrm{~m}$ at Site 673 (Brown, et al., this volume). The thicker prism at Site 673 represents a five-fold increase in sediment overburden, while fluid pressures in the décollement between the deformation front and Site 673 increase only about $15 \%$. As a result, computed fluid pressures in the décollement reach near-lithostatic values only within $2 \mathrm{~km}$ of the deformation front.

Although average pore pressures are higher in the underthrust sediments than in the décollement, they do not reach near-lithostatic pressures (Fig. 10). Because higher fluid pressures exist within the subducted sediments, water flows into the décollement from below. The greater $\lambda^{*}$ values in the décollement vs. the underthrust sediments may help explain why the décollement is the favored domain for active faulting in the toe of the complex. Consequently, the décollement can accommodate relatively high rates of fluid flow while defining the preferred region of decoupling between over- and under-riding sediments.

Table 2. Permeability values that produce flow patterns and fluid pressures consistent with Leg 78A and Leg 110 observations.

\begin{tabular}{lcc}
\hline & $\begin{array}{c}\text { Intrinsic } \\
\text { permeability } \\
\left(\mathrm{m}^{2}\right)\end{array}$ & $\begin{array}{c}\text { Hydraulic } \\
\text { conductivity } \\
\text { (cm/s) }\end{array}$ \\
\hline Prism & $10^{-18}$ to $10^{-19}$ & $10^{-9}$ to $10^{-10}$ \\
Décollement & $10^{-14}$ to $10^{-16}$ & $10^{-5}$ to $10^{-7}$ \\
Underthrust sediments & $10^{-15}$ to $10^{-17}$ & $10^{-6}$ to $10^{-8}$ \\
\hline
\end{tabular}

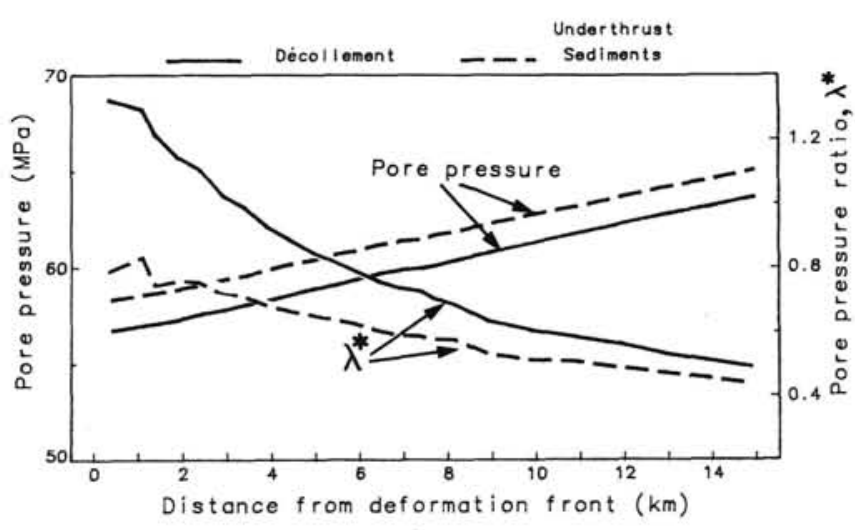

Figure 10. Vertically averaged fluid pressure distribution within the décollement and underthrust sediments for the case illustrated in Figure 4. Pore pressures in the décollement are near-lithostatic near the deformation front. Pore pressures within the underthrust sediments do not reach near-lithostatic levels.

Several simulations that otherwise reproduce the flow constraints result in values greater than 1 in the prism. These simulations suggest that the permeabilities within the prism are not uniform, as treated in the model. Laboratory measurements also indicate that the prism permeability varies with depth. Sediments collected from shallow depths are two to three orders of magnitude more permeable than samples recovered near the base of the prism (Moran, this volume). Preliminary simulations suggest that allowing the equivalent prism permeability $\left(k_{p}\right)$ to decrease with depth while holding the equivalent décollement permeability $\left(k_{d}\right)$ constant results in more realistic pore-pressure distributions in the prism. However, pore pressures and flow paths in the décollement are not affected by the distribution of permeability within the prism if the sediment permeability at the base of the prism is low enough to restrict flow between the décollement and the prism. Thus, assigning a single-prism permeability may lead to unrealistic pore-pressure distributions within the prism, but still preserves the fluid pressure distribution and flow directions within the décollement.

\section{SUMMARY}

The following conclusions can be drawn from our simulations:

1. Near-lithostatic fluid pressures can be simulated at Site 542 only when equivalent prism permeabilities range between $10^{-18}$ and $10^{-19} \mathrm{~m}^{2}$.

2. Limited upward fluid leakage between the décollement and the overlying prism requires a $k_{d} / k_{p}$ contrast of three to four orders of magnitude. Lower $k_{d} / k_{p}$ contrasts result in large upward flows from the décollement into the prism, while higher contrasts result in downward flow from the prism into the décollement. This suggests that the equivalent décollement permeability must be between $10^{-14}$ and $10^{-16} \mathrm{~m}^{2}$.

3. The permeability of the underthrust sequence of sediments does not greatly affect the fluid pressure at Site 542 , or the flow-vector orientation in the décollement.

4. Average regional-scale flow velocities through the décollement may range between 3 and $10 \mathrm{~cm} / \mathrm{yr}$, relative to the deformation front. Regional-scale flow velocities through the prism are much slower, averaging about three orders of magnitude less than in the décollement.

5. Near-lithostatic pore pressures can be simulated to occur within $2 \mathrm{~km}$ of the deformation front in the décollement. Al- 
though pore pressures are higher in the underthrust sediments, they do not reach near-lithostatic levels below the décollement.

\section{ACKNOWLEDGMENTS}

This study was supported by a National Science Foundation Grant, OCE-8609745. We also express our gratitude to Clifford Voss and John Bredehoeft of the U.S. Geological Survey for their useful insights, to David Rogers for providing contour and vector plots, and to the manuscript reviewers for their many comments and suggestions.

\section{REFERENCES}

Bear, J., 1972. Dynamics of Fluids in Porous media: New York (Elsevier).

Brace, W. F., 1980. Permeability of crystalline and argillaceous rocks. Int. J, Rock Mech. Min. Sci. Geomech. Abstr., 17:241-251.

Bredehoeft, J. D., and Hanshaw, B. B., 1968. On the maintenance of anomalous fluid pressures: 1 . Thick sedimentary sequences. Bull. Geol. Soc. Am., 79:1097-1106.

Brown, K. M., and Westbrook, G. K., 1989. Mud diapirism and subcretion in the Barbados Ridge Accretionary Complex: role of fluids in accretionary processes. Tectonics (in press).

Davis, D., Suppe, J., and Dahlen, F. A., 1983. The mechanics of foldand thrust belts and accretionary wedges. J. Geophys. Res., 88: $1153-1172$.

Davis, D. M., 1984. The compressive mechanics of accretionary wedges applied to the Leg 78A study area near Barbados. In Biju-Duval, B., Moore, J. C., et al., Init. Repts. DSDP, 78A: Washington (U.S. Govt. Printing Office), 569-579.

Dorel, J., 1981. Seismicity and seismic gap in the Lesser Antilles arc and earthquake hazard in Guadalupe. Geophys. J. R. Astron. Soc., 67: 679-695.

Gieskes, J., Blanc, G., Vrolijk, P., Moore, J. C., Mascle, A., Taylor, E., Andreieff, P., Alvarez, F., Barnes, R., Beck, C., Behrmann, J., Brown, K., Clark, M., Dolan, J., Fisher, A., Hounslow, M., McLellan, P., Moran, K., Ogawa, Y., Sakal, T., Schoonmaker, J., Wilkens, R., Williams, C., in press. Hydrogeochemistry in the Barbados Accretionary Complex: ODP Leg 110. Tectonophysics.

Hubbert, M. K., and Rubey, W. W., 1959. Role of fluid pressure in mechanics of overthrust faulting. Geol. Soc. Am. Bull., 70:115-166.

Hubbert, M. K., and Willis, D. G., 1957. Mechanics of hydraulic fracturing. J. Petrol. Tech., 9:153-168.

Langseth, M. G., and Hobart, M. A., 1984. A marine geothermal study over deformed sediments of the subduction complex off Oregon and Washington. EOS, 65:1089.

MacDonald, K., and Holcombe, T., 1978. Inversion of magnetic anomalies and seafloor spreading in the Cayman Trough. Earth Planet. Sci. Lett., 40:407-414.

Marlow, M. S., Lee, H. J., and Wright, A. W., 1984. Physical properties of sediment from the Lesser Antilles Margin along the Barbados Ridge: results from Deep Sea Drilling Project Leg 78A. In BijuDuval, B., Moore, J. C., et al., Init. Repts. DSDP, 78A: Washington (U.S. Govt. Printing Office), 549-558.

Minster, J. B., and Jordan, T. H., 1978. Present-day plate motions. J. Geophys. Res., 83:5331-5354.
Moore, J. C., and Biju-Duval, B., 1984. Tectonic Synthesis, Deep Sea Drilling Project Leg 78A: structural evolution of offscraped and underthrust sediment, Northern Barbados Ridge Complex. In BijuDuval, B., Moore, J. C., et al., Init. Repts. DSDP, 78A: Washington (U.S. Govt. Printing Office), 601-621.

Moore, J. C., Mascle, A., Taylor, E., Alvarez, F., Andreieff, P., Barnes, R., Beck, C., Behrmann, J., Blanc, G., Brown, K., Clark, M., Dolan, J., Fisher, A., Gieskes, J., Hounslow, M., McClellan, P., Moran, K., Ogawa, Y., Sakai, T., Schoonmaker, J., Vrolijk, P. J., Wilkens, R., Williams, C., 1987. Expulsion of fluids from depth along a subduction-zone décollement horizon. Nature, 326:785-788. 1988. Tectonics and hydrogeology of the northern Barbados Ridge: results from Ocean Drilling Program Leg 110. Geol. Soc. Am. Bull., 100:1578-1593.

Morin, R., and Silva, A. J., 1984. The effects of high pressure and high temperature on some physical properties of ocean sediments. J. Geophys. Res., 89:511-526.

Morrow, C. A., Shi, L. Q., Byeriee, J. D., 1984. Permeability of fault gouge under confining pressure and shear stress. J. Geophys. Res., 89:3193-3200.

Neuzil, C. E., 1986. Groundwater flow in low permeability environments. Water Resour. Res., 22:1163-1195.

Shi, Y., and Wang, C.-Y., 1985. High pore pressure generation in sediments in front of the Barbados Ridge Complex. Geophys. Res. Lett., 12:773-776.

1988. Generation of high pore pressures in accretionary prisms: inferences from the Barbados Subduction Complex. J. Geophys. Res., 93:8893-8909.

Stein, S., DeMets, C., Gorden, R. G., Brodhoff, J., Argus, D., Engeln, J. F., Lundgren, P., Stein, C., Wiens, D. A., Woods, D. F., 1988. A test of alternative Caribbean Plate relative motion models. J. Geophys. Res., 93:3041-3040.

Tovish, A., and Schubert. G., 1978. Island arc curvature, velocity of convergence and angle of subduction. Geophys. Res. Lett., 5:329332.

von Huene, R., and Lee, H., 1983. The possible significance of pore fluid pressures in subduction zones. In Watkins, J. S., and Drake, C. L. (Eds.), Studies of Continental Margin Geology: AAPG Mem., 34:781-791.

Voss, C. I., 1984. A finite element simulation model for saturated-unsaturated, fluid-density-dependent groundwater flow with energy transport or chemically-reactive single-species solute transport. U.S. Geol. Surv. Water Resour. Invest., 84-4369:409

Westbrook, G. K., and Smith, M. J., 1983. Long décollements and mud volcanoes: evidence from the Barbados Ridge Complex for the role of high pore-fluid pressure in the development of an accretionary complex. Geology, 11:279-283.

Wright, A., 1984. Sediment distribution and depositional processes operating in the Lesser Antilles intraoceanic island arc, eastern Caribbean. In Biju-Duval, B., Moore, J. C., et al., Init.Repts. DSDP, 78A: Washington (U.S. Govt. Printing Office), 301-324.

Date of initial receipt: 14 March 1988

Date of acceptance: 5 April 1989

Ms 110B-165 